\title{
EDITORIAL
}

\section{Berat Badan Lahir Rendah, Solusi dan Dampak yang Ditimbulkannya}

Berat badan lahir rendah atau yang disingkat dengan BBLR masih menjadi permasalahan di dunia, khususnya di negara-negara berkembang. BBLR adalah bayi dilahirkan dengan berat badan kurang dari 2500 gram, termasuk lahir prematur ataupun cukup bulan. Lebih dari 20 juta bayi di dunia $(15,5 \%$ dari seluruh kelahiran) mengalami BBLR dan 95\% diantaranya terjadi di negaranegara berkembang. Laporan Riskesdas 2013 menunjukkan bahwa persentase BBLR di Indonesia sebesar 10,2\%.

Beberapa penelitian menunjukkan bahwa faktor risiko terjadinya BBLR adalah faktor Ibu, seperti penyakit yang berhubungan langsung dengan kehamilan misalnya perdarahan antepartum, trauma fisik dan psikologis, diabetes mellitus, usia ibu yang terlalu muda (kurang dari 20 tahun), ibu menderita kurang energi kronis (KEK), mempunyai kebiasaan merokok. Dari faktor janin adalah Hidramion, kehamilan ganda dan kelainan kromosom. BBLR memiliki banyak konsekuensi yang merugikan. Bayi Berat Lahir Rendah (BBLR) merupakan penyumbang utama kematian neonatal. Di negara-negara berkembang seperti Indonesia morbiditas dan mortalitas akibat BBLR masih tinggi. Masalah BBLR merupakan masalah yang perlu mendapat perhatian. Bayi BBLR mempunyai risiko untuk dikemudian hari seperti penyakit kardiovaskular, diabetes mellitus dan obesitas di usia dewasa. BBLR dapat menyebabkan gangguan perkembangan fisik, pertumbuhan terhambat dan gangguan perkembangan mental pada masa mendatang. Tingkat kecerdasan anak yang lahir BBLR lebih rendah dibandingkan dengan anak yang lahir dengan berat badan lahir normal. Kelahiran BBLR sebagian disebabkan oleh lahir sebelum waktunya (prematur), dan sebagian karena mengalami gangguan pertumbuhan selama masih dalam kandungan (Pertumbuhan Janin Terhambat). Menurut perkiraan World Health Organization (WHO), terdapat 5 juta kematian neonatus setiap tahun dengan angka mortalitas neonatus (kematian 28 hari pertama kehidupan) adalah 34 per 1000 kelahiran hidup dan 98\% kematian ini berasal dari negara berkembang.

Stunting (anak pendek) merupakan bentuk dari gangguan pertumbuhan, hal ini terjadi akibat defisiensi zat gizi saat dalam kandungan, asupan zat gizi yang tidak adekuat dan sering terjadi penyakit infeksi pada usia balita terutama pada dua tahun pertama kehidupan. Laporan Riskesdas tahun 2013 menunjukkan bahwa prevalensi stunting adalah $37,2 \%$, artinya satu dari tiga anak Indonesia tergolong pendek.

Di negara berkembang, termasuk Indonesia kurang gizi sebelum kehamilan dan ketika hamil ditambah lagi dengan status kesehatan yang buruk dengan adanya penyakit penyerta kehamilan, akan berdampak pada lahirnya anak IUGR (Intra Uterine Growth Retardation) dan BBLR. Apabila tidak ada perbaikan IUGR maka BBLR akan terus berlanjut ke generasi berikutnya. Siklus ini akan terjadi apabila tidak ada perbaikan gizi dan pelayanan kesehatan yang tidak optimum.

Perbaikan ini diutamakan pada seribu hari kehidupan (1000 HPK) yaitu 270 hari selama kehamilan dan 730 hari pada kehidupan pertama bayi yang dilahirkan. 1000 HPK merupakan periode yang sensitif karena akibat yang ditimbulkan pada bayi pada masa ini bersifat permanen dan tidak bisa dikoreksi. Pentingnya 1000 HPK, mulai dari kehamilan sampai anak berusia dua tahun menjadi fokus perhatian yang merupakan periode emas. Bank Dunia menyebut periode ini sebagai "Window of Opportunity". Segala perbaikan diluar periode tersebut tidak dapat mengatasi permasalahan yang ada dengan tuntas.

Pemantauan kesehatan selama kehamilan sangatlah penting. Hal ini untuk mengetahui segala macam permasalahan kesehatan ibu hamil dan janin yang dikandungnya. Penelitian yang dilakukan oleh Ani Triana yang berjudul "Pengaruh penyakit penyerta kehamilan dan kehamilan ganda dengan kejadian bayi berat lahir rendah di RSUD Arifin Achmad Provinsi Riau" menunjukkan bahwa ibu dengan penyakit peyerta kehamilan lebih beresiko 10 kali untuk melahirkan BBLR. Ibu dengan 
kehamilan ganda lebih berisiko 15 kali melahirkan BBLR. Untuk menurunkan dan mencegah terjadinya BBLR, maka selama hamil ibu dapat memeriksakan kondisi kesehatannya pada tenaga kesehatan minimal 4 kali selama kehamilan.

Permasalahan BBLR adalah permasalahan yang menyangkut seluruh siklus kehidupan. Bayi yang lahir dengan berat rendah apabila tidak ditangani dengan baik dengan pemberian makanan yang tidak adekuat, sering menderita penyakit infeksi sehingga kejar tubuh (catch up) yang tidak adekuat menyebabkan tubuh anak-anak yang pendek (stunting).
Hal ini akan berlanjut ketika usia dewasa tetap pendek, dan ketika masa kehamilan menderita Kurang Energi Protein (KEK) dan sering menderita penyakit, maka apabila melahirkan, akan melahirkan bayi BBLR.

Pemerintah sudah mengeluarkan kebijakan 1000 HPK mulai dari kehamilan sampai usia dua tahun. Pada periode inilah perbaikan gizi dan kesehatan diutamakan untuk memutus mata rantai permasalahan BBLR. 